\title{
Evidence of otitis media and mastoiditis in a Medieval Islamic skeleton from Spain and possible implications for ancient surgical treatment of the condition \\ By Júlia Olivé-Busoma, Olalla López-Costas ${ }^{b, c, d}$, Miquel Quer-Agustíe, Nicholas Márquez-Grant ${ }^{\dagger}$, Helena Kirchner ${ }^{a}$
}

\footnotetext{
a Departament de Ciències de l'Antiguitat I l'Edat Mitjana, Universitat Autònoma de Barcelona, Cerdanyola del Vallès, 08193, Spain. helena.kirchner@uab.cat

${ }^{b}$ Group EcoPast (GI-1553), Universidade de Santiago de Compostela, Santiago de Compostela, 15782, Spain. olalla.lopez@usc.es

${ }^{\mathrm{c}}$ Archaeological Research Laboratory, Stockholm University, Wallenberglaboratoriet, SE-10691 Stockholm, Sweden

¿ Laboratorio de Antropología Física, Facultad de Medicina, Universidad de Granada, Granada 18012, Spain

e Departament de Cirurgia Àrea d'Otorrinolaringologia, Universitat Autònoma de Barcelona, Cerdanyola del Vallès, 08193, Spain. mquer@santpau.cat

${ }^{f}$ Cranfield Forensic Institute, Cranfield University, Defence Academy of the United Kingdom, Shrivenham SN6 8LA, United Kingdom. n.marquezgrant@cranfield.ac.uk
}

Corresponding author: Júlia Olivé-Busom (julia.olive@uab.cat)

\section{Abstract}

Objective: To evaluate lesions on a cranium from the Iberian Peninsula and assess its medico-historical and paleopathological significance.

Materials: The skeletal remains of a juvenile individual found in a Medieval Islamic grave $\left(10^{\text {th }}-16^{\text {th }}\right.$ century) in Eastern Spain.

Methods: Macroscopic examination of the left and right temporal bones, binocular microscopy, X-ray, and Scanning Electron Microscopy - Energy Dispersive X-ray Spectroscopy (SEM-EDS) were performed.

Results: A sub-oval perforation superior to the right mastoid process and pathological changes on the right temporal bone were identified. SEM-EDS confirmed the presence of copper in the surrounding area of the perforation.

Conclusions: The observed pathological changes are most likely compatible with otitis media and subsequent mastoiditis. The sub-oval perforation could be interpreted either as an abscess or as evidence of a surgical procedure (mastoidectomy) or a combination of both; and the $\mathrm{Cu}$ traces may be the result of an associated object or, possibly, the application of a plaster with copper acetate used as medical treatment.

Significance: This case contributes to the paleopathological record and the interpretation of similar cases, and also helps in the understanding of medical care and treatment in Medieval Islam.

Limitations: The lack of similar pre-modern cases of surgical intervention limits comparability to clinical cases.

Suggestion for further research: Exploration into indicators of health care in past populations. Keywords: mastoidectomy, copper staining, Al-Andalus, History of Medicine, Medieval Spain 


\section{Introduction}

Otitis media $(\mathrm{OM})$ is one of the most common diseases treated with antibiotics in children (Casselbrant \& Mandel, 2010; Chole \& Sudhoff, 2010; Qureishi et al., 2014). It involves the inflammation of the middle ear and the obstruction of the Eustachian tube, which in turn causes an infection to develop (Abelló \& Quer, 1992:55). Two types of OM can be distinguished: acute otitis media (AOM) and chronic otitis media (COM). AOM develops from an acute and usually bacterial infection of the middle ear and is typically found in children (Mora et al., 2014:23). Conversely, COM has a polymicrobial origin and is characterized by the absence of pain, otorrhea, and it is more commonly found in adults (Abelló \& Quer, 1992:57-58). OM, especially in infants and juveniles, can result in physical and social disability (Klein, 2000; Rovers et al., 2004; Casselbrant \& Mandel, 2010; Chole \& Sudhoff, 2010). If the infection is left untreated, two kinds of complications may occur: intra-temporal, and intracranial complications--all of which require surgical intervention (Mora et al., 2014:23). The most common intra-temporal complication is mastoiditis, which is characterized by the spread of the bacterial colonization into the mastoid air cells, causing local destruction (Mora et al., 2014:23). Mastoiditis manifests by fever, suppuration, and painful swelling around the region of the mastoid process of the temporal bone (Abelló \& Quer, 1992:63). In pre-antibiotic societies, untreated mastoiditis could have been life-threatening, as the infection could affect the endocranium (Hamidi et al., 2008). This complication is usually found in children suffering from AOM and today is commonly treated surgically to remove pus and exudate (Abelló \& Quer, 1992:65; Mora et al., 2014:25). Although surgical interventions to drain suppuration have been undertaken since antiquity, the first recorded clinical case of mastoidectomy dates back to the $18^{\text {th }}$ century (Guerrier \& Mounier-Khun, 1980:36).

Ear infection diagnosis in paleopathology is challenging, as diagnosis today relies on soft tissue. However, its identification in past populations provides valuable insights into the population to which the individual belonged, the medical resources available, and care for the sick. Only a few studies of OM within archaeological populations have been published (see Qvist \& Grontved, 2001; Flohr \& Schultz 2009a; Armentano et al., 2014; Krenz-Niedbała \& Łukasik, 2016). Most publications that identify OM include an initial macroscopic assessment of the auditory canal, the middle ear, and the ossicles, which in most cases is combined with microscopy, radiography, and other imaging techniques. These usually identify changes to the auditory meatus and/or ossicles, abscesses, cavitation, and sclerotization resulting from active and recurrent remodelling (v.g. Qvist \& Grontved, 2001; Collin \& Judd, 2015; Krenz-Niedbała \& Łukasik, 2016; Zhang et al., 
2020). Abscesses are more frequent in OM, but may also be a complication of cholesteatoma. Cholesteatoma is an aggregation of dead epidermal cells that causes a cystic lesion that affects the middle ear and petrosal bone causing a serious ear infection (Nevoux et al., 2010). Although uncommon, childhood cholesteatoma tends to be more aggressive than the adult form, but rarely develops a labyrinthine fistula (Nevoux et al., 2010). Paleopathological cases of cholesteatoma have been identified through macroscopic, radiographic, and microscopic assessment (Qvist \& Grontved, 2001; Mays \& Holst, 2006; Armentano et al., 2014). Most publications that report mastoiditis include radiographs or computed tomography, since the state of pneumatization of the mastoid air cells is essential for assessment (Homøe \& Lynnerup, 1991; Homøe et al., 1996; Macías et al., 1999; Flohr \& Schultz 2009a and b; Zhang et al., 2020).

This paper aims to analyze an unusual OM sequela from Medieval Spain and to explore whether indicators of medical treatment are present. It is hoped that this case can add to the existing, albeit limited, paleopathological literature and be used as comparative material for scientists investigating similar changes related to ear infection.

2. Material and Methods

In 1995, an archeological rescue excavation uncovered 37 graves, which followed Islamic funerary rites in the town of Vall d'Uixó (Figure 1) (Castellón, Eastern Spain). In accordance with this rite, no associated grave goods were found, but the position and orientation of the bodies provided a wide date between the $10^{\text {th }}$ and the $16^{\text {th }}$ centuries AD (Cara, 1993; Casal, 2001). Contextual information regarding the settlement(s) associated with the cemetery is limited due to the nature of the rescue excavations in the area. For this reason, a wider perspective that focuses on the living conditions in rural populations in Al-Andalus as a whole has been undertaken. One of the graves (Grave 12) contained a partially complete, but well preserved (Grade 1 according to McKinley, 2004), skeleton of an individual aged between 10 and 15 years at the time ofdeath according to dental development (Ubelaker, 1979) and skeletal maturation (Schaefer et al., 2009). The skull was mostly complete, as well as the limb bones, whilst other elements were only partially recovered (see Supplement Material 1). 


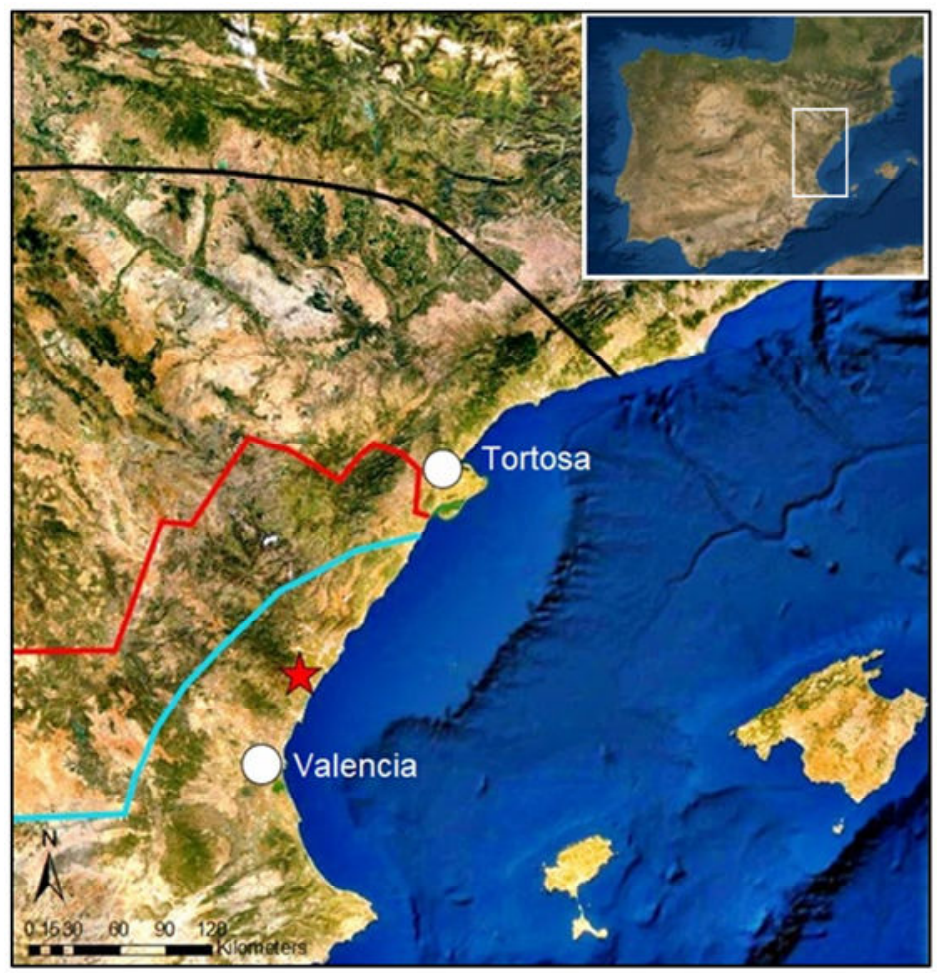

Figure 1. Location of Vall d'Uixó in the Iberian Peninsula, marked with a red star. The border between AlAndalus and the Christian kingdoms is represented as it moved towards the south: in black the frontier in the early $11^{\text {th }}$ century, in red during the mid-12 $2^{\text {th }}$ century, and in blue during the early $13^{\text {th }}$ century. After 1238 the region was conquered by the Christian Kingdoms.

A macroscopic analysis of the skeleton was undertaken. A binocular microscope was used to observe and record the pathological changes on the temporal bone. Radiographs were taken with a portable RALCO XR collimator and a standard adjustment of $66 \mathrm{kV} \times 4.0 \mathrm{mAh}$ that was modified according to imaging requirements. Scanning Electron Microscopy - Energy Dispersive X-ray Spectroscopy (SEM-EDS) was performed with an EVO MA10 on variable pressure at a magnification ranging from 20 to $50 \mathrm{X}$ and an accelerating voltage of $20 \mathrm{kV}$.

\section{Results}

The right temporal bone presented a sub-oval perforation of a maximum diameter of $12 \mathrm{~mm}$, located superior to the mastoid process (Figure 2). The edges of this perforation were smooth and rounded, whilst the interior wall of the perforation presented a slight osteoblastic response and pitting (Figure 3). Pitting was also observed on the external lamina surrounding the external auditory meatus, alongside blood vessel canals suggesting intense vascularity (Figures 2 and 3a). New bone formation (irregular woven bone) was identified on the inferior wall (Figure 3a). Slight post-mortem damage was also present on some aspects around the rim, noted as white areas of exposed bone (Figures $3 a, 3 b, 3 c$ ). This perforation reached the petrous pyramid creating an opening 
into the auditory canal at the level of the posterior wall of the middle ear (retrotympanum) (Fig. 4). The external auditory meatus and canal showed no signs of pathological alteration, enlargement, or bone resorption. In the middle ear, however, there is bone destruction involving most of the retrotympanum, which connects with the mastoid process perforation (Figure 4). Part of the superior wall (epitympanum) was also affected, but the infection did not perforate the tegmen timpani (Figure 4a). The pyramid also presents some alteration in the form of erosion. However, the structures of the middle ear, such as the oval and round windows (fenestra ovalis, fenestra rotunda) or the vestibule aquaeductus Fallopii, are preserved and have normal appearance (Figure 4a). Likewise, the inner surface of the temporal bone revealed a normal and therefore nonpathological internal auditory meatus, aquaeductus vestibuli, and aquaeductus cochleae. There were no pathological conditions on the left temporal bone.

Radiographs of the right temporal bone revealed a higher density around the edges of the perforation. The mastoid air cells of the left mastoid process displays normal pneumatization, although the tip of the mastoid process, which is affected by postmortem damage, could be hypocellular (Figure 5a). Meanwhile, the right mastoid process displays abnormal pneumatization that could be compatible with mixed or diploic bone (Figure 5b) (Sadé \& Fuchs, 1994; Sethi et al., 2006; Cinamon, 2009; du Boulay, 2016:199-200; Flohr et al., 2019). The ear ossicles were not preserved.

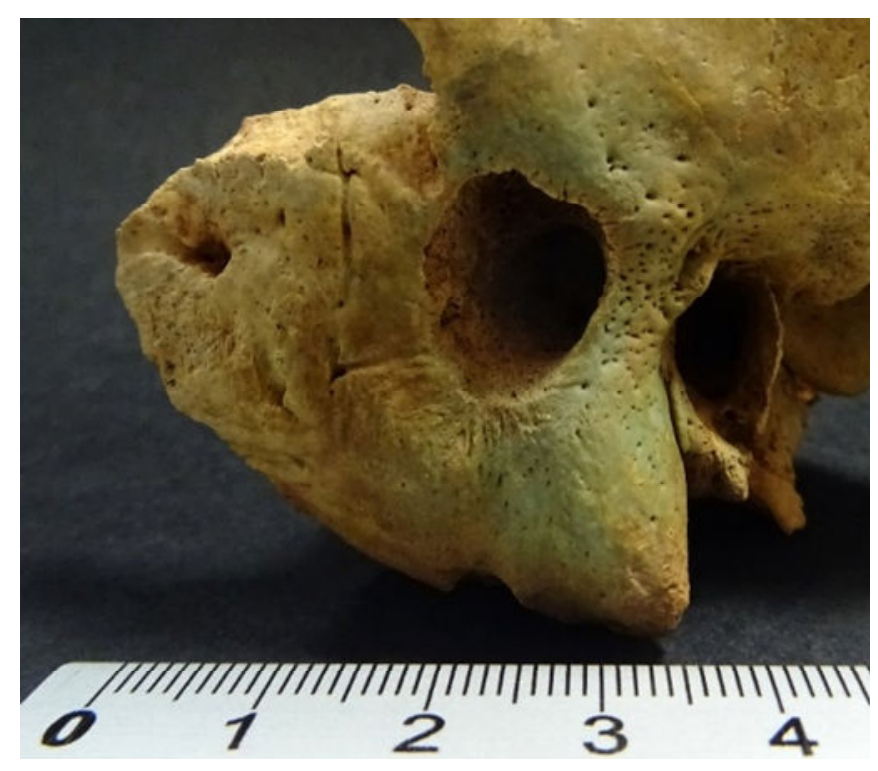

Figure 2. Observed perforation, pitting, and woven bone on the right temporal bone. 

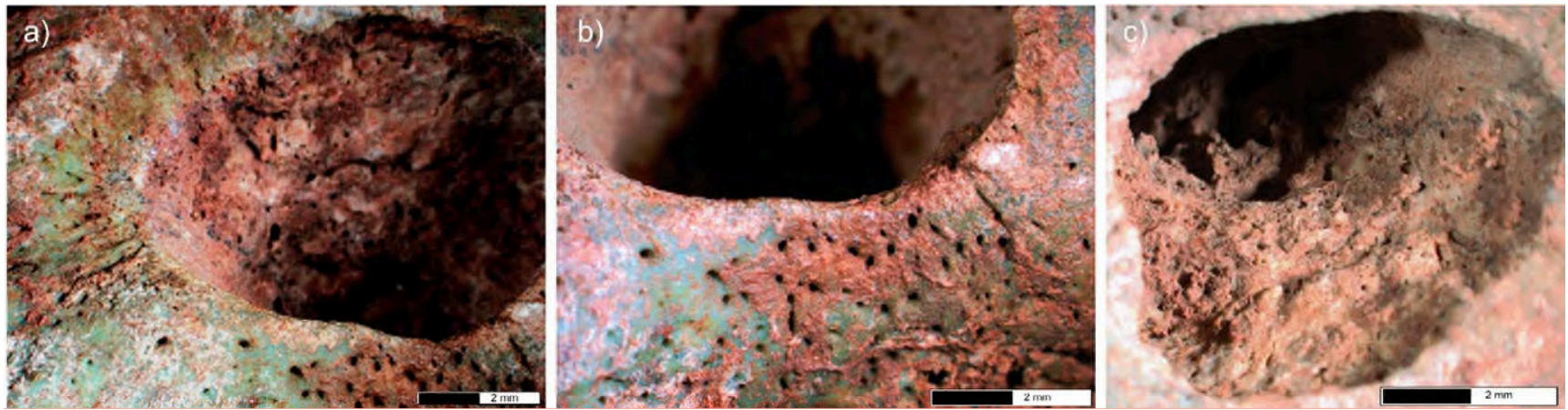

Figure 3. Detailed images of the perforation. a) Edges of the perforation, which appear smooth and rounded.

The image is focused on the inferior and anterior aspects. b) Pitting found surrounding the perforation. The image is focused on the anterior aspect. c) Possible woven bone formation and slight pitting. The image is focused on the inferior view of the wall.
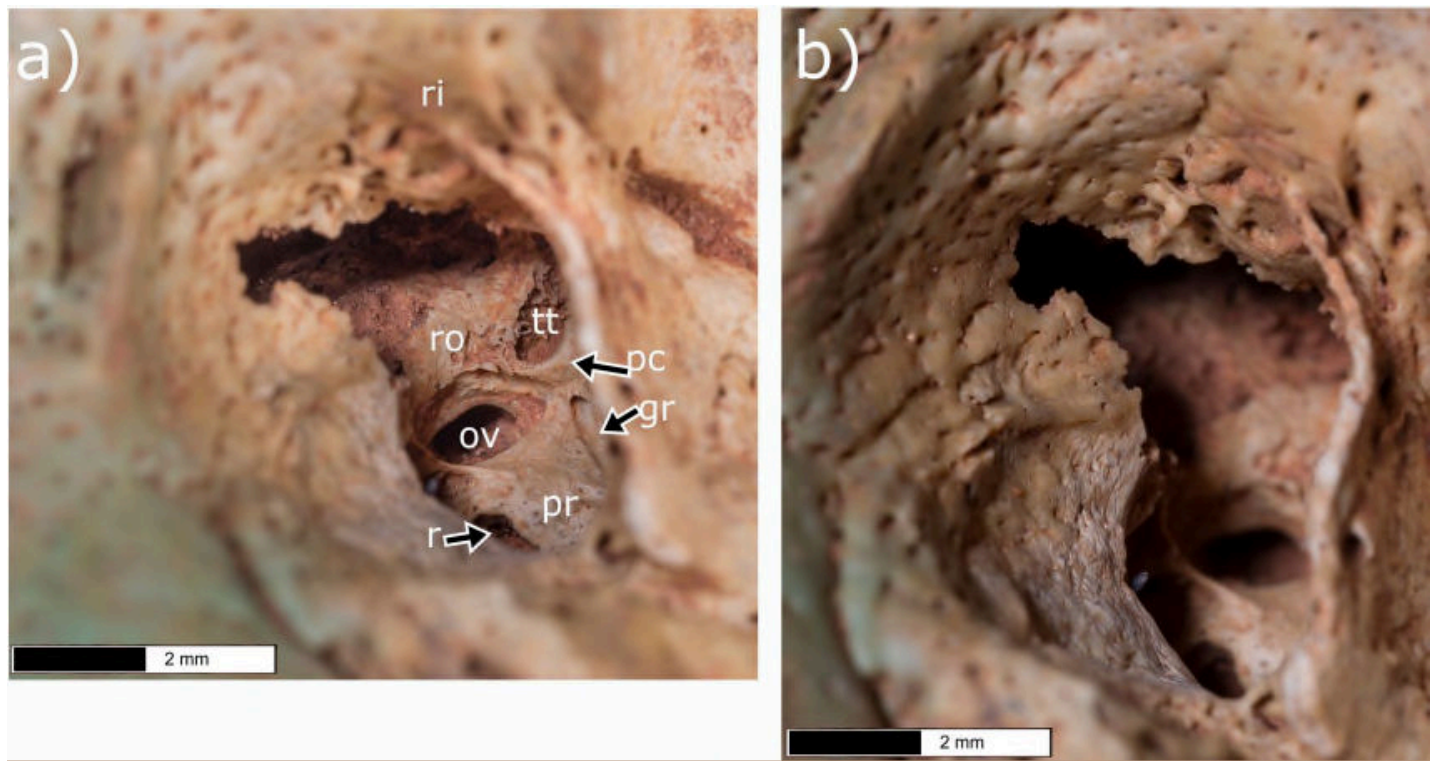

Figure 4. Right middle ear showing preservation of normal structure. a) View of the middle ear's structures. Notes: ri, notch of Rivenus; ro, roof of aqueductus fallopii (canal for facial nerve); tt, canal for the tensor tympani; ov, oval window; pc, processus cochleariformis; r, round window; pr, promontory; gr, groove for tympanic plexus. b) General view of the auditory canal and posterior-superior aspects of the middle ear showing the erosive lesion that connects with the perforation.

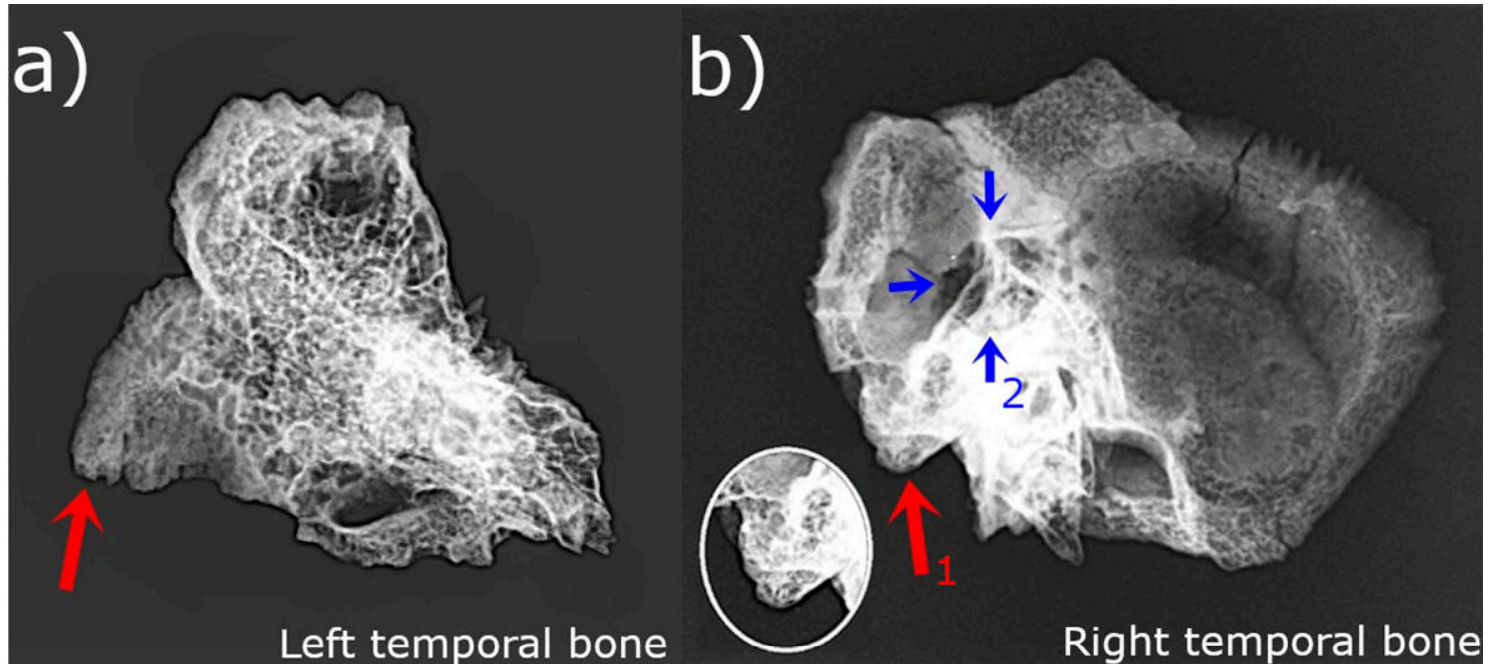


Figure 5. Radiograph of the temporal bones $60 \mathrm{kV} \times 6.4 \mathrm{mAh}$. a) Lateral view of the left temporal bone. Arrow points to the mastoid process. b) Lateral view of the pathological right temporal bone. The mastoid air cells show diploic bone. Arrows point at the mastoid process (1), which is amplified inside the circle, and the borders of the perforation (2).

Linear enamel hypoplasia (LEH) was observed on both the anterior dentition (100\%, 4/4) and the posterior dentition $(10 \%, 1 / 10)$, with the following teeth being affected: the central incisors, the right lateral incisor, the right canine, and the first premolar. No other pathological changes were detected cranially or postcranially.

A green discoloration was present on the right mastoid process. This may have been caused by contact with copper or a copper alloy (Hopkinson et al., 2008; Dupras \& Schultz, 2013). Moreover, EDS analysis showed that areas with this coloration had significant copper content (1.5\%), while adjacent areas with no coloration had no detectable copper. SEM images show blood vessel grooves posterior to the lesion (see Supplemental Material 2).

\section{Discussion}

The new bone formation and bone erosion observed on the external lamina of the right temporal's mastoid process, as well as on the wall of the perforation, is compatible with descriptions of $\mathrm{OM}$ and mastoiditis in the paleopathological record (Flohr \& Schultz 2009a and b; García \& Polo, 2011; Krenz-Niedbała \& Łukasik, 2016). This is also true for the pitting observed on the anterior margin of the perforating lesion adjacent to the external auditory meatus (Figure $3 b$ ).

Regarding the perforation, the relative smoothness of the margins, especially the inferior aspect (Figure $3 b$ ), points to an in vivo origin of the perforation in the external table. This fact, together with the vascularity and new bone formation in the inferior wall of the perforation (Figure 3), and a higher density around its edges may be indicative of healing. Although its diameter is wide in comparison to the majority of perforations on the mastoid process diagnosed as abscesses caused by an ear infection, some other cases share similar characteristics. Loveland and colleagues (1990) studied temporal bones with extensive damage and interpreted the damage as resulting from abscesses caused by mastoiditis. Those abscesses with sharper edges were documented as still being active at the time of death. In comparison, this case presented here shows signs of healing; however, an abscess cannot be dismissed. The cavity involved the petrous pyramid, creating an opening into the middle ear. Upon comparison with clinical cases, no signs of an abscess involving the inner ear could be found (Mora et al., 2014:26; Kösling, 2017; Pont \& Mazón, 2017). If this was the case, it could point towards circumscribed labyrinthitis, an abscess in the inner ear usually secondary to a cholesteatoma (see 
below), which can cause vertigo, and without adequate treatment can lead to intracranial complications (Mora et al., 2014: 25-26).

Clinical literature presents cases of cholesteatoma that can produce penetrating defects in the bone and can be secondary to OM (v.g. Nishihira, 2000; Smith \& Danner, 2006; Campbell et al., 2017). The new bone formation (Figure 3a and c), and the presence of pitting on the surrounding area and the inside of the perforation (Figure 3b), may be evidence of an infection and do not seem compatible with what has been reported in the paleopathological literature (Qvist \& Grontved, 2001; Mays \& Holst, 2006; Armentano et al., 2014). Although both radiographic examination (following criteria from GrahamHodgson, 1950; du Boulay, 2016:197) and the preservation of the structures of the middle ear did not indicate its presence, the possibility of a cholesteatoma cannot be ruled out.

Taking these observations into consideration, as well as the age-at-death of the individual, a probable diagnosis is that of $\mathrm{OM}$, possibly acute, and which resulted in mastoiditis. As stated above, the perforation could be an abscess caused by the infection. However, it must be considered that this perforation may be intentional (surgical) due to three key observations: 1) the perforation connects the middle ear with the mastoid cells; 2) its location and dimensions, and 3) the possible presence of a mastoidectomy. Similar cases have been identified in bioarcheology, whilst the clinical literature offers many examples (Kvestad et al., 2000; Garap \& Dubey; 2001; Vercellotti et al., 2010; Boljunčić \& Hat, 2015; Dourado et al., 2016; Magalhães et al., 2017).

According to clinical and surgical literature (Abelló \& Quer, 1992), the location of the perforation would support surgical intervention to treat mastoiditis, since its location is less prone to cause complications, avoiding damage to the endocranium, the facial nerve, and the lateral vessel (Abelló \& Quer, 1992:63-64). The characteristics are also similar to a Medieval case from Croatia, which was interpreted as the work of an experienced surgeon (Boljunčić \& Hat, 2015). A similar perforation described by Brothwell (1974) in a Roman individual from York was attributed to surgical intervention using a trepan. In addition, two other publications present possible cases of mastoidectomies in modern, yet pre-antibiotic, populations from Italy and Portugal (Vercellotti et al., 2010; Magalhães et al., 2017). The latter case on the left mastoid process has an almost identical location to the present case and has been interpreted as having occurred during post-mortem medical training (Magalhães et al., 2017). A review of the medico-historical literature of Medieval Islam shows that physicians had the knowledge to perform interventions, as they were well versed in ear infections and anatomy of the ear (Azizi, 2007; Liñán et al., 2014; Hajdu, 2016). One such physician was Avicenna, who includes a treatise on 
otology in his Canon of Medicine, where he recommended drainage in case of an abscess (Azizi, 2007; Hamidi et al., 2008).

The green staining surrounding the perforation is likely post-mortem, for example the result of contact with a shroud pin (Schultz, 2012). These have been found in other Islamic cemeteries of the peninsula and could have been part of the shroud used in the Islamic burial ritual (Casal, 2001; Navarro, 2018; López \& Martín, 2019). Although uncommon, some excavations find them associated with the skeleton without mention of their exact location (Galve \& Benavente, 1992; Baños \& Martínez, 1998; López et al., 2014). In addition, other artifacts such as earrings could have caused this coloration (see Casal, 2001; López et al., 2014). However, this is rare in Islamic burial ritual and in the studied population, and no other skulls with similar discoloration have been found. Thus, the above observations and the unilaterality of the discoloration, may suggest another interpretation. Medieval Islamic treatises mention the use of copper acetate or verdigris to treat inflammations, clean wounds, and aid cicatrization (Peña \& Girón, 2001; Chavoushi et al., 2012; Emami et al., 2012; Liñán et al., 2014). Furthermore, in his treatise on otology, Avicenna mentions the use of verdigris in the treatment of various types of ear conditions (Hamidi et al., 2008). This may link the presence of copper around the perforation to surgical intervention and subsequent medical treatment. There is no clear evidence, however, on how in vivo medical procedures on soft tissue can alter the color of the bone; unless perhaps the individual in treatment at the time of death had been buried with bandage or any other material that had copper acetate. The study of elemental quantitative composition on different bone types could reveal more information about pre-mortem or post-mortem copper acquisition (López-Costas et al., 2016). Although the interpretation of surgical intervention is undoubtedly a possibility, no conclusive evidence has been reached to date, and it is therefore still a possibility that the staining is due to the burial environment and funerary rite (e.g. shroud pin).

There are several published examples of ear infection in paleopathology. Three are of special interest here, as they belong to the same period and cultural group and were populations that lived less than $30 \mathrm{~km}$ away from this present case. These consist of two possible cases of OM and a possible case of mastoiditis (García \& Polo, 2011; Forner, unpublished). Clinical studies state that cold temperatures, low socioeconomic status, overcrowding in the family home, short duration of breastfeeding, the presence of older siblings, poor hygiene, and malnutrition, amongst other factors, all influence the prevalence of OM and post-treatment complications (Ståhlberg et al., 1986; Uhari et al., 1996; Paradise et al., 1997; Klein, 2000; Garap \& Dubey, 2001; Dhooge, 2003; Rovers et al., 2004; Kong \& Coates, 2009). These settlements are in the vicinities of Sierra de 
Espadán, a mountain range where temperatures can drop to -4ํㅡ (IVIA, 2019). Moreover, the current individual presents LEH, which can be related to various factors including nutrition deficiencies, low socioeconomic background, and infectious diseases (Goodman et al., 1988; Lukacs et al., 2001; King et al., 2005; Lewis, 2017:84-85). Therefore, it is possible that both LEH and the OM sequela point towards an individual that suffered chronic stress. In addition, rural Andalusian populations lived in houses with extended family members, and even though most of daily life revolved around the patio, rural homes usually had two to three rooms; thus, it is possible that children were often in contact with each other and that the sleeping space was overcrowded (Trillo, 2006; Orihuela, 2007). In the case of breastfeeding however, women tended to breastfeed for up to two years, and often appear in medical treatises as the ones caring for the sick child (Álvarez et al., 1984; Ávila, 1995; Cabanillas, 2012).

\section{Conclusion}

Through macroscopic, microscopic, and radiological analysis of the observed alteration to the right temporal bone, and the consultation of clinical and paleopathological literature, specific skeletal changes have been diagnosed as resulting from a major ear infection on the right temporal bone. It is likely that the individual first developed OM, which resulted in mastoiditis. From this point forward, different interpretations can be provided regarding the perforation. On one hand, the perforation could correspond to an abscess, which could be associated with a cholesteatoma; on the other hand, it could be compatible with surgical intervention (a mastoidectomy). Likewise, this lesion could be the result of the combination of both. The paleopathological record presents other cases of extensive damage to the mastoid process region of the temporal bone that have been identified as abscesses; while other pre-modern and clinical studies have proposed that similar lesions were the result of mastoidectomies. At some point after developing the lesion, the presence of copper around the affected area could represent an association with pharmacological treatment through the use of copper acetate; however, other options such as post-mortem contact with a pin or an earring are also possible. Limited contextual and archaeological information, as well as the possible differential diagnoses, do not allow any further precision.

Certainly, this case study presents an unusual lesion in paleopathology with interesting implications for the understanding of medical knowledge, medical access, and everyday life in rural Al-Andalus. 


\section{Acknowledgments}

The authors wish to thank the staff of Museu Arqueològic Municipal de la Vall d'Uixó, Dr Raquel Piqué for kindly lending the binocular microscope used for imaging. We would also like to thank Dr Ignasi Galtés for his discussion over this case, as well as the Centre de Restauració de Béns Mobles de Catalunya for their help in obtaining the images of the middle ear structures. The authors would also like to thank the anonymous reviewers for providing detail feedback which led to an improvement in the quality of the manuscript. We would also like to thank Dr Jennifer Grant for proofreading this manuscript.

\section{Funding}

JOB is financed by a FPU doctoral contract (FPU17/02934) granted by Ministerio de Ciencia, Innovación y Universidades. OLC is financed by Plan Galego GPC (ED431B 2018/20), granted by Xunta de Galicia. The project Órdenes agrarios y conquistas ibéricas (siglos XII-XVI). Estudios desde la arqueología histórica (HAR2017-82157-P) sponsored by the Spanish Ministerio de Ciencia, Innovación y Universidades has funded this research.

\section{References}

Abelló, P., \& Quer, M. (1992). Manual d'oto-rino-laringologia. Bellaterra.

Álvarez, C., Girón, F. G., Fíaz, A., \& Peña, C. (1984). El niño enfermo en los textos médicos andalusíes. Dynamis, 4, 265-276.

Armentano, N., Malgosa, A., Martínez, B., Abelló, P., de Juan, M., Prats-Muñoz, G., \& Isidro, A. (2014). Unilateral cholesteatoma in the first millennium BC. Otology \& Neurotology, 35(3), 561-564.

Ávila, M. L. (1995). La estructura de la familia en al-Andalus. In J. Navarro (Ed.), Casas y Palacios de al-Andalus (pp. 33-37). Lunwerg.

Azizi, M. H. (2007). The otorhinolaryngologic concepts as viewed by Rhazes and Avicenna. Archives of Iranian Medicine, 10(4), 552-555.

Baños, J., \& Martínez, J. A. (1998). Aportación al estudio de la maqbara islámica de Alhama de Murcia: Excavación en la calle Fulgencio Cerón Cava, n.ำ 2. Memorias de Arqueología, 13, 319-334.

Boljunčić, J., \& Hat, J. (2015). Mastoid trepanation in a deceased from Medieval Croatia: A case report. Collegium Antropologicum, 39(1), 209-214. 
Brothwell, D.R. (1974). Osteological evidence of the use of a surgical modiolus in a Romano-British population: an aspect of primitive technology. Journal of Archaeological Science, 1(2), 209-211.

Cabanillas, M. I. (2012). La mujer en Al-Ándalus. In Archivo Histórico Diocesano de Jaén (Ed.), IV Congreso Virtual sobre historia de las mujeres. Archivo Histórico Diocesano de Jaén.

Campbell, B. R., Yawn, R. J., O'Connell, B. P., \& Rivas, A. (2017). Dermoid tumor of the middle ear: A case report and review of the literature. Otolaryngology Case Reports, 4, 18-20.

Cara, L. (1993). Historia de Almería: La civilización islámica. Instituto de Estudios Almerienses.

Casal, M.T. (2001). Los cementerios islámicos de Qurtuba. Anales de arqueología cordobesa, 12, 283-313.

Casselbrant, M., \& Mandel, E. (2010). Acute otitis media and otitis media with effusion. In C. Cummings, J. Frederickson, \& L. Harker (Eds.), Otolaryngology: Head \& Neck Surgery (pp. 2761-2777). Elsevier Mosby.

Chavoushi, S. H., Ghabili, K., Kazemi, A., Aslanabadi, A., Babapour, S., Ahmedli, R., \& Golzari, S. E. (2012). Surgery for Gynecomastia in the Islamic Golden Age: Al-Tasrif of Al-Zahrawi (936-1013 AD). ISRN Surgery, 1-5.

Chole, R.A., \& Sudhoff, H.H. (2010). Chronic otitis media, mastoiditis and petrositis. In C Cummings, J Frederickson, L Harker (Eds.), Otolaryngology: Head \& Neck Surgery (pp. 1964-1978). Elsevier Mosby.

Cinamon, U. (2009). The growth rate and size of the mastoid air cell system and mastoid bone: a review and reference. European Archives of Oto-Rhino-Laryngology, 266(6), 781-786.

Dhooge, I. J. (2003). Risk factors for the development of otitis media. Current Allergy and Asthma Reports, 3(4), 321-325.

Dourado, R., Cabral, F., de Oliveira, A. C., \& Ferreira, R. F. (2016). Mastoid obliteration with autologous bone in mastoidectomy canal wall down surgery: a literature overview. International Archives of Otorhinolaryngology, 20(1), 76-83.

du Boulay, G. H. (2016). Principles of X-ray Diagnosis of the Skull. ButterworthHeinemann. 
Dupras, T. L., \& Schultz, J. J. (2013). Taphonomic bone staining and color changes in forensic contexts. In J. Pokines \& S.A. Symes (Eds.), Manual of Forensic Taphonomy (pp. 315-340). CRC Press.

Emami, S. A., Sahebkar, A., Tayarani-Najaran, N., \& Tayarani-Najaran, Z. (2012). Cancer and its treatment in main ancient books of Islamic Iranian traditional medicine (7th to 14th Century AD). Iranian Red Crescent Medical Journal, 14(12), 747.

Flohr, S., \& Schultz, M. (2009a). Osseous changes due to mastoiditis in human skeletal remains. International Journal of Osteoarchaeology, 19(1), 99-106.

Flohr, S., \& Schultz, M. (2009b). Mastoiditis-paleopathological evidence of a rarely reported disease. American Journal of Physical Anthropology, 138(3), 266-273.

Flohr, S., Hartmann, A. K., Kierdorf, H., Schultz, M., \& Kierdorf, U. (2019). Histomorphological study on hypocellularity in mastoid processes from archaeological human skeletons. International Journal of Paleopathology, 26, 27-36.

Forner, A.B. (unpublished report). Estudio antropologico y paleopatologico de la necrópolis del almudín (Segorbe).

Galve, P., \& Benavente, J. A. (1992). La necrópolis islámica de la Puerta de Toledo de Zaragoza. In Asociación Española de Arqueología Medieval (Ed.), Actas del III Congreso de Arqueología Medieval Español (pp. 383-387). Universidad de Oviedo.

Garap, J. P., \& Dubey, S. P. (2001). Canal-down mastoidectomy: experience in 81 cases. Otology \& Neurotology, 22(4), 451-456.

García, E., \& Polo, M. (2011). Bioantropología y paleopatología de tres necrópolis medievales de Burriana: el Palau, Portal de Valencia, iglesia del Salvador. In J. M. Melchor, J. Benedito \& T. Pasíes (Eds.), La arqueología de la Buriyyana islámica a la Borriana cristiana (pp.63-100). Ajuntament de Borriana.

Goodman, A. H., Brooke Thomas, R., Swedlund, A. C., \& Armelagos, G. J. (1988). Biocultural perspectives on stress in prehistoric, historical, and contemporary population research. American Journal of Physical Anthropology, 31(S9), S169-S202.

Graham-Hodgson, H. (1950). Radiology of the infected temporal bone. Proceedings of the Royal Society of Medicine, 43, 43.52.

Guerrier, Y., \& Mounier-Kuhn, P. (1980). Histoire des maladies de l'oreille, du nez et de la gorge: les grandes étapes de l'oto-rhino-laryngologie. R. Dacosta.

Hajdu, S. I. (2016). Pathfinders in oncology from ancient times to the end of the Middle Ages. Cancer, 122(11), 1638-1646. 
Hamidi, S., Sajjadi, H., Boroujerdi, A., Golshahi, B., \& Djalilian, H. R. (2008). Avicenna's treatise on otology in Medieval Persia. Otology \& Neurotology, 29(8), 1198-1203.

Homøe, P. \& Lynnerup, N. (1991). Pneumatization of the temporal bones in a Greenlandic Inuit anthropological material. Acta oto-laryngologica, 111(6), 1109-1116.

Homøe, P., Lynnerup, N., Skovgaard, L.T. \& Rasmussen, N. (1996). Estimation of otitis media in ancient populations: A study of past and present Greenlandic Inuit. The Journal of Laryngology \& Otology, 110(12), 1114-1119.

Hopkinson, K. A., Yeats, S. M., \& Scott, G. R. (2008). For whom the coin tolls: green stained teeth and jaws in medieval and post-medieval Spanish burials. Dental Anthropology, 21(1), 12-17.

IVIA (2020). Segorbe. Available at: http://riegos.ivia.es/listado-de-estaciones/segorbe

King, T., Humphrey, L. T., \& Hillson, S. (2005). Linear enamel hypoplasias as indicators of systemic physiological stress: Evidence from two known age-at-death and sex populations from postmedieval London. American Journal of Physical Anthropology, 128(3), 547-559.

Klein, J. O. (2000). The burden of otitis media. Vaccine, 19 (S1), S2-S8.

Kong, K., \& Coates, H. L. (2009). Natural history, definitions, risk factors and burden of otitis media. Medical Journal of Australia, 191(S9), S39-S43.

Kösling, S. (2017). Anatomy and Pathology of the Temporal bone. In K. Nikolaou, F. Bamberg, A. Laghi \& G. Rubin (Eds.), Multislice CT (pp. 137-146). Springer.

Krenz-Niedbała, M., \& Łukasik, S. (2016). Skeletal Evidence for Otitis Media in Mediaeval and Post-Mediaeval Children from Poland, Central Europe. International Journal of Osteoarchaeology, 27(3), 375-386.

Kvestad, E., Kværner, K. J., \& Mair, I. W. (2000). Acute mastoiditis: predictors for surgery. International Journal of Pediatric Otorhinolaryngology, 52(2), 149-155.

Lewis, M. (2017). Paleopathology of children: Identification of pathological conditions in the human skeletal remains of non-adults. Academic Press.

Liñán, M., Carrasco, J., \& Guijarro, E. L. (2014). Fósiles y minerales en la obra de Avenzoar (Ibn Zuhr), médico sevillano del siglo XII. Naturaleza aragonesa, 31, 54-59.

López , F., Delaporte, S., Benedito, J., Claramonte, M., \& Melchor, J. M. (2014). A propósito de unas púas de rastrillo y otros materiales metálicos de época medieval procedentes de Sagunto. Quaderns de Prehistòria i Arqueologia de Castelló, 32, 241256. 
López-Costas, O., Lantes-Suárez, Ó., \& Cortizas, A. M. (2016). Chemical compositional changes in archaeological human bones due to diagenesis: Type of bone vs soil environment. Journal of Archaeological Science, 67, 43-51.

López, U., \& Martín, J. (2019). De cementerio andalusí a centro documental: la maqbara de Fuerte de Santiago. Mil años de huesos, armas y libros. Almoraima, 50, 95-110.

Loveland, C. J., Pierce, L. C., \& Gregg, J. B. (1990). Ancient temporal bone osteopathology. Annals of Otology, Rhinology \& Laryngology, 99(2), 146-154.

Lukacs, J. R., Nelson, G. C., \& Walimbe, S. R. (2001). Enamel hypoplasia and childhood stress in prehistory: new data from India and Southwest Asia. Journal of Archaeological Science, 28(11), 1159-1169.

Macías, M., Villanueva, A., Mateo, A., \& Ruzaperez-Barquero, M. (1999). Enfermedades otológicas halladas en una muestra de población púnica y romana de Cádiz. In J. A. Sánchez (Ed.), Actas del V Congreso Nacional de Paleopatología (pp. 1-10). Asociación Española de Paleopatología - Ayuntamiento de Alcalá la Real.

Magalhães, B. M., Lopes, C., \& Santos, A. L. (2017). Differentiating between rhinosinusitis and mastoiditis surgery from postmortem medical training: A study of two identified skulls and hospital records from early 20th century Coimbra, Portugal. International Journal of Paleopathology, 17, 10-17.

Mays, S., \& Holst, M. (2006). Palaeo-otology of cholesteatoma. International Journal of Osteoarchaeology, 16(1), 1-15.

McKinley, J.I. (2004). Compiling a skeletal inventory: disarticulated and commingled remains. In M. Brickley \& J.I. McKinley JI (Eds.), Guidelines to the Standards for Recording Human Remains (pp. 14-17). BABAO.

Mora, E., Rosell A., \& Daza M. J. (2014). Manual CTO. Otorrinolaringologia. CTO.

Navarro, M. (2018). La maqbara del camino de Bayyāsa (Marroquíes Bajos, Jaén). Lucentum, 37, 281-303.

Nevoux, J., Lenoir, M., Roger, G., Denoyelle, F., Ducou Le Pointe, H., \& Garabédian, E.N. (2010). Childhood cholesteatoma. European Annals of Otorhinolaryngology, Head and Neck Diseases 127, 143-150.

Nishihira, S. (2000). Epidermal Cyst of the Tympanic Membrane. A Case Report. Otolaryngology Head and Neck Surgery-Tokyo-, 72(9), 605-608.

Orihuela, A. (2007). La casa andalusí: un recorrido a través de su evolución. Artigrama, 22, 299-335. 
Paradise, J. L., Rockette, H. E., Colborn, D. K., Bernard, B. S., Smith, C. G., Kurs-Lasky, M., \& Janosky, J. E. (1997). Otitis media in 2253 Pittsburgh-area infants: prevalence and risk factors during the first two years of life. Pediatrics, 99(3), 318-333.

Peña, C., \& Girón, F. (2001). Medicina versus cirugía: el tratamiento de las enfermedades de los ojos en las obras de Abulcasis y Avenzoar. Dynamis, 21, 163-187. Pont, E., \& Mazón, M. (2017). Indications and Radiological Findings of Acute Otitis Media and Its Complications. Acta Otorrinolaringologica, 68(1), 29-37.

Qureishi, A., Lee, Y., Belfield, K., Birchall, J. P., \& Daniel, M. (2014). Update on otitis media-prevention and treatment. Infection and Drug Resistance, 7, 15-24.

Qvist, M., \& Grøntved, A. M. (2001). Chronic otitis media sequelae in skeletal material from medieval Denmark. The Laryngoscope, 111(1), 114-118.

Rovers, M. M., Schilder, A. G., Zielhuis, G. A., \& Rosenfeld, R. M. (2004). Otitis media. The Lancet, 363(9407), 465-473.

Sadé, J., \& Fuchs, C. (1994). A comparison of mastoid pneumatization in adults and children with cholesteatoma. European Archives of Oto-Rhino-Laryngology, 251(4), 191195.

Schaefer, M., Black, S. M., \& Scheuer, L. (2009). Juvenile osteology. Academic Press.

Schultz, J. J. (2012). Determining the forensic significance of skeletal remains. In D. C. Dirkmaat (Ed.), A Companion to Forensic Anthropology (pp. 66-84). Blackwell.

Sethi, A., Singh, I., Agarwal, A.K., \& Sareen, D., 2006. Neumatización de las Células Mastoideas: Rol de Factores Adquiridos. International Journal of Morphology, 24(1), 3538.

Smith, J. A., \& Danner, C. J. (2006). Complications of chronic otitis media and cholesteatoma. Otolaryngologic Clinics of North America, 39(6), 1237-1255.

Ståhlberg, M. R., Ruuskanen, O., \& Virolainen, E. (1986). Risk factors for recurrent otitis media. Pediatric Infectious Disease, 5(1), 30-32.

Trillo, M. C. (2006). La alquería y su territorio en Al-Andalus: estrategias sociales de organización y conservación. Arqueología espacial, 26, 243-262.

Ubelaker, D.H. (1979). Human Skeletal Remains: Excavation, Analysis and Interpretation. Smithsonian Institute Press.

Uhari, M., Mäntysaari, K., \& Niemelä, M. (1996). Meta-analytic review of the risk factors for acute otitis media. Clinical Infectious Diseases, 22(6), 1079-1083. 
Vercellotti, G., Williams, L. L., \& Stout, S. D. (2010). Two possible cases of mastoidectomy from a recent Italian ossuary (Chiavarl, GE). Paleopathology Newsletter, 151, 13-18.

Zhang, X., Zhao, Y., Niu, Y., Wang, Z. \& Zeng, W. (2020). Two probable cases of mastoiditis in a cemetery from the Warring States to Han Dynasty (475 BCE-220 CE) in Qufu, Shandong Province, China. International Journal of Paleopathology, 30, 77-84.

Appendix A. Supporting material

Supplement figure 1. Visual inventory of skeleton.

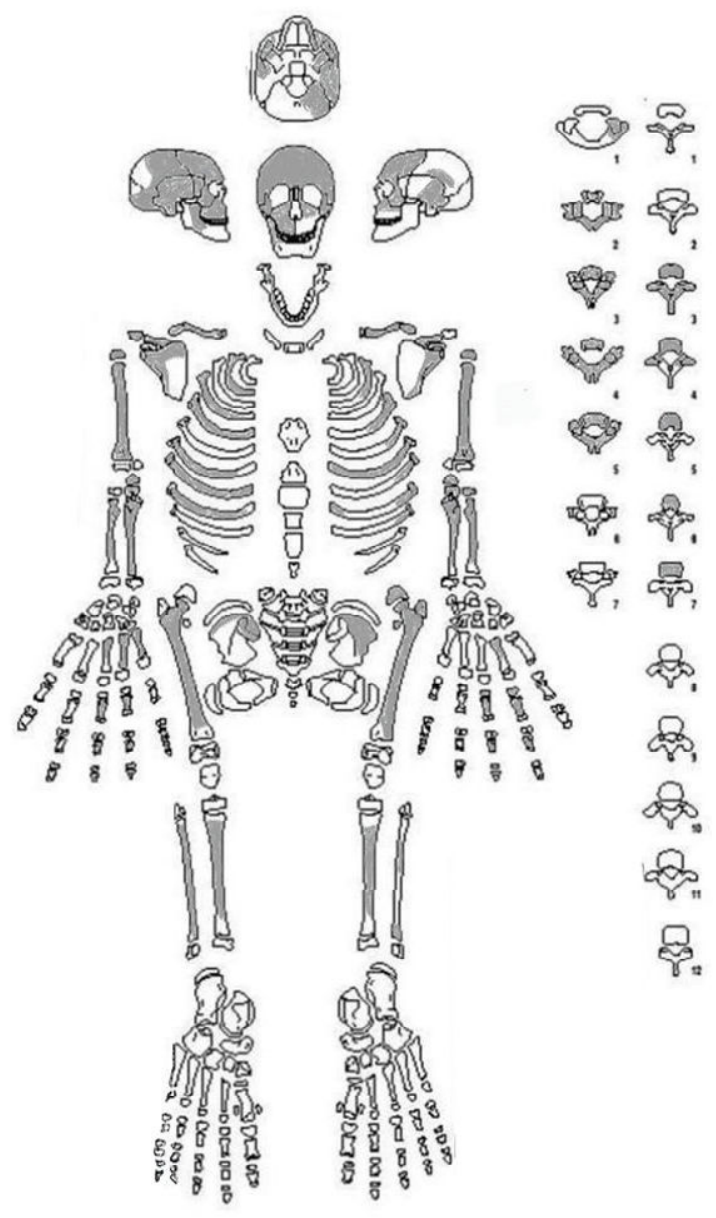

Supplement figure 2. SEM image showing the smooth surface of the blood vessel grooves located at the posterior external margin of the lesion (at the inferior rim level). 


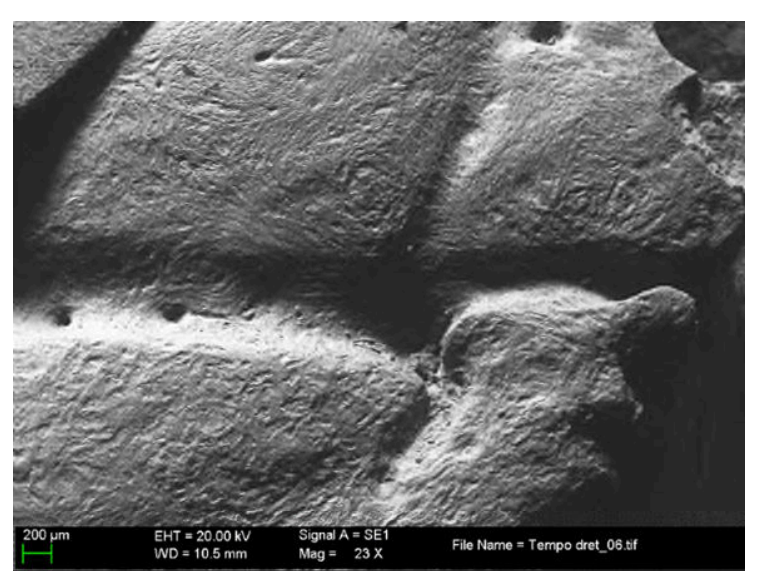

